\title{
JUEGOS DE PALO EN LARA. ELEMENTOS PARA LA HISTORIA SOCIAL DE UN ARTE MARCIAL VENEZOLANO ${ }^{1}$
}

POR

\author{
MATTHIAS RÖHRIG ASSUNÇÃO
}

Historiador. Universidad de Essex, Inglaterra

\begin{abstract}
Este trabajo intenta situar a los juegos de palo venezolanos dentro de una perspectiva más amplia de las artes marciales europeas y afro-americanas. Analiza las diferentes modalidades practicadas desde el siglo XIX por los hombres del campo en Lara, Estado donde se conservó su práctica hasta hoy en día. Mientras el Juego de Garrote servía y sirve para fines recreativos y deportivos, el Juego de Batalla era y es parte de la devoción a San Antonio. Los procesos criminales muestran cómo el uso del garrote permitió la construcción de una identidad masculina («el guapo») a través de las frecuentes riñas entre hombres en el período 1880-1930.
\end{abstract}

El rápido desarrollo de las artes marciales en el mundo postmoderno ha generado muchas discusiones y una voluminosa literatura al respecto de los más conocidos. No obstante, el Juego de Garrote, considerado con razón por sus practicantes un método genuinamente venezolano de defensa personal, no ha recibido, hasta aho-

1 El presente trabajo es el resultado parcial de un proyecto de investigación más largo financiado generosamente por la Fundación Alemana para la Investigación Científica (Deutsche Forschungsgemeinschaft, DFG). Marys García me ayudó en la recogida de datos en el Registro Principal de Barquisimeto. Agradezco también a los funcionarios del Registro, Maria Luisa Linares de Infante, Dionisio Perdomo Freitez e Iván Vallenilla Osorio, el apoyo de Eduardo Sanoja, Irene Zerpa, Luzmira Zerpa y Ramón Sarmiento, así como la revisión del español por Alejandro Méndez (Universidad de Essex) y Luis Ricardo Dávila (Universidad de Los Andes, Mérida). 
ra, la debida atención ${ }^{2}$. De hecho, hoy en día hasta su misma existencia es desconocida por muchas personas en Venezuela.

Una de las razones de eso es que la práctica del juego de palo en Venezuela se restringe actualmente sobre todo al Estado Lara. Es importante diferenciar tres modalidades de juegos de palo que han existido en esta región. Primero, el palo como simple arma fue usado con frecuencia en la historia de Venezuela, tanto en las guerras civiles como en enfrentamientos más limitados («riñas»), utilizándose una o varias técnicas de combate. Existe una modalidad más elaborada que contiene reglas y ciertos «rituales», llamado Juego de Garrote (venezolano o tocuyano) ${ }^{3}$. El Juego de Garrote en ese sentido es más que un simple método de defensa personal, ya que su práctica tiene también fines recreativos. Se practica con una pareja (y no adversario), en sitios especiales («patios»), por lo general bajo la supervisión de un profesor (que puede ser «maestro» o no). En suma, cuando es practicado en esas circunstancias, es también una diversión y hoy, un deporte. Debido a esto, considero, en contra de algunos estu$\operatorname{diosos}^{4}$, que la denominación «juego» es muy adecuada.

El carácter lúdico del entrenamiento no impide que el practicante se prepare al mismo tiempo para cualquier eventualidad, o sea un enfrentamiento real con un adversario en una situación de pelea, la riña. El límite entre lo que es diversión pura y pelea seria pasa por estadios intermedios con fronteras más o menos bien delimitadas. Así, el estudiante avanzado practica el «Juego de Riña» que es casi una pelea verdadera. Por otro lado, las fuentes históricas de que disponemos sugieren que muchas riñas que acabaron con heridos $o$ inclusive muertos, comenzaron como «juegos».

\footnotetext{
2 Los estudios pioneros sobre el tema son: Eduardo SANOJA, Juego de Garrote Larense. El método venezolano de defensa personal, Caracas; Federación Nacional de la Cultura Popular, 1984; Eduardo SANOJA e Irene ZERPA, El Garrote en nuestras letras, Los Rastrojos (Lara), Talleres tipográficos de Miguel Angel García e Hijo, 1990; Jesús CANELóN, «El Juego de Garrote», Fermentum. Revista Venezolana de Sociología y Antropología, 4, 10, Mérida, 1994, pp. 22-32. Para una bibliografía y hemerografia, véase Eduardo SANOJA, Juego de Palos o Juego de Garrote. Guía bibliohemerográfica para su estudio, Los Rastrojos (Lara), Asociación Venezolana de Jugadores de Garrote, Patio de Garrote «Clarencio Flores», 1996.

3 Algunos practicantes del garrote en la zona del Tocuyo tienden a agregarle el adjectivo «tocuyano», para enfatizar el origen del juego de esa ciudad. Véase por ejemplo Argimiro GonZÁLEZ, El juego del garrote Tocuyano, El Tocuyo (Lara), 1995.

4 Canelón, [2], p. 24.
} 


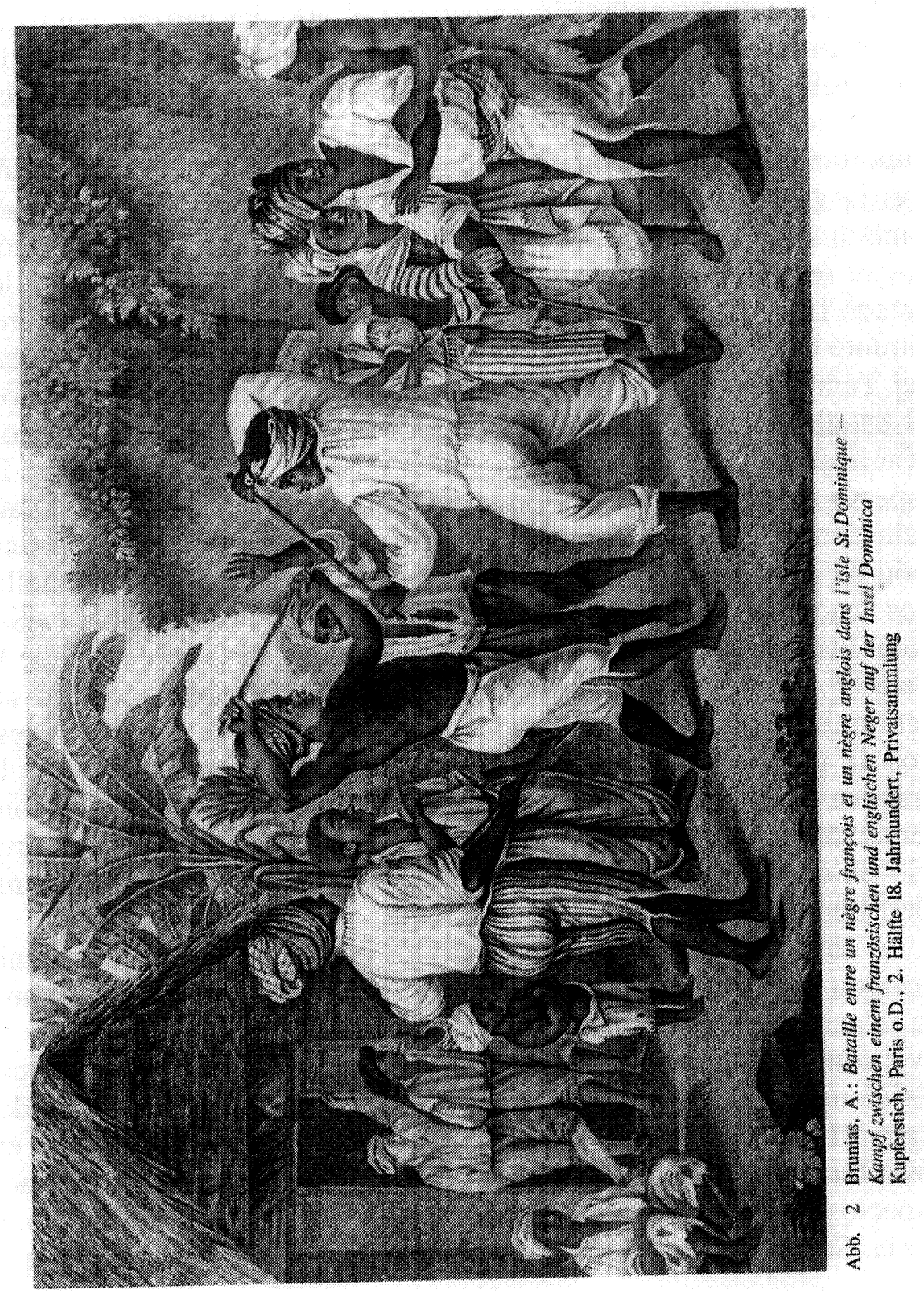

En muchas islas del Caribe los esclavos negros practicaban juegos de palo.

Fuente: A. BRUNIAS, Bataille entre un nègre françois et un nègre anglois dans l'isle St. Dominique. Colección Privada. Reproducido de C. MIDDELANIS [22], con el permiso del Dr. Marcel Chatillon (París). 
Finalmente, es necesario considerar el arte del garrote dentro de una manifestación popular más amplia, asociado con música y baile, con profundas implicaciones religiosas. En el Tamunangue, principal baile 'folclórico' del Estado Lara, el garrote tiene una función importante dentro de una devoción a un santo, por su identificación con la vara de San Antonio. El Tamunangue acrecenta un mundo simbólico extremadamente complejo al garrote en toda la región donde se acostumbra festejarlo, o sea hoy en día la mayor parte del Estado Lara ${ }^{5}$. El Juego de Batalla, que es ejecutado por dos hombres durante la procesión del santo o al iniciarse los siete «sones» (bailes) del Tamunangue, difiere del Juego de Garrote en muchos sentidos. El batallero debe «respetar al santo», o sea, no le es permitido golpear a su adversario. Hay también una serie de golpes prohibidos. El aspecto devocional es, sin duda, el primordial en esta modalidad. Aún dentro del Tamunangue el garrote continúa teniendo una función de entretenimiento, por eso se habla del «Juego» de la Batalla. Los maestros que no son batalleros (Mercedes Pérez, Eduardo Sanoja) insisten sobre la diferencia entre el Juego de Garrote y el de la Batalla $^{6}$. Tienen razón, ya que hoy en día muchos batalleros no saben ya jugar garrote. No obstante, en la medida que muchos maestros de garrote son también batalleros, y tomando en cuenta que la práctica del Juego de Batalla seguramente fue responsable de la conservación del Juego de Garrote, que se habría extinguido como ocurrió en otras regiones de Venezuela ${ }^{7}$, resulta difícil separarlo completamente del Tamunangue.

A continuación discutiré primero los posibles orígenes y la significación de las diferentes modalidades de juegos de palo, así como su relación con otras manifestaciones similares en las Américas y el «viejo mundo». Luego analizaré el lugar del garrote en la violencia cotidiana en el Estado Lara, o sea, en los «brollos» y «riñas» del siglo XIX y XX. Pienso que un enfoque sobre el uso del garrote en los diferentes contextos sociales puede ayudarnos a entender algunos aspectos cruciales de la mentalidad y de la cultura popular de Venezuela. Se trata de una primera evaluación de fuentes de archivo, que

5 Véase el mapa de difusión del Tamunangue en Isabel ARETZ, El Tamunangue, Barquisimeto, Italgráfica, 1970.

6 SANOJA, [2], pp. 25-26; Mercedes Pérez, entrevista, La Piedad (Lara), noviembre de 1992.

7 SANOJA y ZeRPa, [2], p. 35.

R. I., $1999, \mathrm{n}^{\circ} 215$ 
he venido investigando en los ultimos años. Quiero someter a discusión algunos datos, conclusiones e hipótesis preliminares, previas a un trabajo más substancial que incluirá más datos de la historia oral. Espero así incentivar el debate en torno a este tema en Venezuela, y contribuir también a que el garrote sea en el futuro considerado parte integrante del campo de las artes marciales afro-americanas.

\section{EL GARROTE VENEZOLANO Y LAS ARTES MARCIALES DEL MUNDO ATLÁNTICO}

Cualquier discusión sobre los posibles orígenes de los juegos de palo en Venezuela se establece en un terreno extremamente movedizo. Las razones residen tanto en la escasa documentación histórica como en las implicaciones ideológicas de cualquier conclusión a ese respecto. La preeminencia de un origen étnico servirá inexorablemente de argumento atribuyendo mayor contribuición de la cultura de esa etnia o «raza» a la cultura popular venezolana. La insistencia sobre su venezolanidad puede alimentar cualquier discurso nacionalista en búsqueda de símbolos para manipular. Creo que, al igual de lo que pasó con la Capoeira, el hoy famoso arte marcial afro-brasileño, ese tipo de debates podrían presentarse también para el Juego de Garrote. Las reflexiones que siguen deben ser leídas entonces como una primera y provisional aproximación al tema.

Hay una fuerte tradición en los estudios folclóricos latinoamericanos de descomponer cualquier manifestación cultural en elementos aislados, que son atribuidos entonces a sus orígenes. Las categorías fundamentales en ese ejercicio son, por lo general, «el» indio, «el» negro, «el» europeo, o «el» español. Esa visión no solamente desconsidera las fundamentales diferencias entre las etnias amerindias, africanas o ibéricas, sino que tampoco reconoce el hecho de que en sociedades jerárquicas, la cultura se puede estructurar en subculturas, características de grupos sociales específicos, como por ejemplo, élites urbanas, clases subalternas rurales, marginales urbanos, o grupos profesionales. Este tipo de enfoque tampoco considera la importancia de la historia colonial o decimonónica como generadora de cultura. En efecto, la historiografía más reciente ha mostrado que lo «tradicional» suele ser, por lo general, mucho más reciente de lo que aparenta ser. Así, la cuestión de los orígenes puede resultar 
falsa en la medida que impone una visión ahistórica de un «orígen» que puede ser datado, y a partir del cual una «esencia» inmutable es transmitida hasta el presente. Este enfoque esencialista no permite observar la complejidad de procesos formativos de manifestaciones culturales como el Juego de Garrote o el Tamunangue.

Tampoco es posible analizar una manifestación de cultura popular en términos cuantitativos, es decir, los diferentes elementos (técnicas, ritual, espíritu o filosofía) pueden tener un peso muy distinto cuando se trata de apreciar su carácter. Para la discusión de los orígenes, diferenciaré, por el momento, lo que es técnica de combate, de lo que es juego, y de lo que es además, un baile y una devoción. En un segundo momento intentaré discutir la relación entre las tres modalidades.

Hasta ahora, la discusión sobre la génesis tanto del Juego de Garrote como de la Batalla, se ha preocupado en mostrar posibles antecedentes de los dos, o manifestaciones similares con el mismo origen en otros países. Parece necesario sistematizar estas comparaciones para llegar a conclusiones más sólidas. Más particularmente, hace falta comparar no solamente las técnicas o músicas empleadas, sino también los grupos sociales envueltos, las reglas y rituales adoptados, y la filosofía o el «espíritu» de las manifestaciones relevantes. Hay que interrogarse también sobre el proceso de la transmisión de los conocimientos y prácticas.

Hasta ahora se han barajado varios orígenes tanto para el Juego de Garrote como para la Batalla: española, o más generalmente europea, canaria (guanche), amerindia y eventualmente, africana.

Como señaló Eduardo Sanoja, la pelea de palos es casi universal, existiendo en muchas culturas distintas en Africa, Asia y Latinoamérica. En Europa occidental, la esgrima del bastón francesa y el bastón inglés son los artes más conocidos e influentes, existiendo modalidades de menos impacto como el bastón portugués, o el juego de cañas francés ${ }^{8}$. Estos últimos autores sugieren que la lucha hubiera podido ser introducida en Venezuela por piratas franceses o ingleses.

Aunque posible, esta hipótesis no explica por qué el garrote logró tanta popularidad en los Andes larenses, y no en el litoral fre-

8 Vease para mas detalles SANOJA y ZerPa, [2], pp. 17-21; Francisco Antonio Ossorio ACEVEDo, El Juego del Palo Canario, según los Verga, La Esperanza, Tenerife, ed. del autor, 1978, pp. 27-35.

R. I., $1999, \mathrm{n}^{\circ} 215$ 
cuentado por los piratas. Por otro lado, se sabe que el Juego de Garrote fue practicado en Maracaibo y hay indicios de su práctica en la región de Coro. De hecho, el garrote como arma fue usado regularmente en toda Venezuela desde la época colonial ${ }^{9}$.

No obstante existe mucha afinidad entre las técnicas de bastón inglés o de la esgrima francesa y las del garrote venezolano, afinidad que puede muy bien ser de origen reciente. Algunos de los más famosos maestros aprendieron técnicas europeas que acabaron integradas al Juego de Garrote en fecha bastante cercana. Baudilio Ortiz (1889-1995) manejaba y se inspiraba en libros de esgrima europeos ${ }^{10}$, que también fue aparentemente el caso de Ismael Colmenares $^{11}$. El maestro León Valera aprendió directamente con un inglés residente en Lara ${ }^{12}$. Así, la coincidencia puntual de algunas técnicas en la actualidad no puede ser considerado un fuerte indicio para trazar el origen del arte.

De la misma manera, existe una serie de similitudes ente el Juego de Garrote y una modalidad del palo canario llamado "palo chico», apuntados por Sanoja ${ }^{13}$, que se refieren al vocabulario para designar el movimento de los pies (cuadra/cuadro) o las técnicas (puntas), así como en la preparación del palo o la manera como se practicaba («fuera de las miradas curiosas»). Esas similitudes, que se extienden a la mentalidad de los jugadores ${ }^{14}$, sugieren una considerable influencia del palo canario sobre el garrote, lo que parece también plausible por la fuerte presencia de migrantes canarios en Venezuela, desde la época colonial hasta la actualidad. Ossorio Acevedo sugiere la sobrevivencia, en Venezuela, de técnicas y juegos canarios ya desaparecidos en las Islas ${ }^{15}$. El propio «palo chico» es una modalidad casi en extinción en las Islas Canarias, donde los juegos de palo de lejano origen guanche han conservado su popularidad.

9 De eso hay numerosas pruebas en fuentes históricas o literarias. Hemos encontrado referencias al uso del garrote en regiones tan lejanas de Lara como en la provincia de $\mathrm{Cu}$ maná en el Oriente de Venezuela.

10 ARETZ, [5], p. 83; SANOJA, [2], p. 61.

11 Entrevista con Felix García, Barquisimeto, 11.11.1992.

12 CANELÓn, [2], p. 28.

13 Eduardo SANOJA, Símiles, texto manuscrito, Gran Canária, 1996.

14 SANOJA y ZeRPa, [2], pp. 22-23.

15 Francisco Antonio Ossorio ACEvedo, «Juego del Palo», F. A. Ossorio A. y Pedro Cardenes Rodrígues, Tradiciones Canarias. Juego del Palo. Peleas de Gallo, Las Palmas, Gran Canaria, Edirca, 1987, p. 37. 
El posible origen o influencia amerindia hasta ahora no ha tenido muchos adeptos. Canelón señala la existencia de armas de madera entre algunas etnias, pero más bien en regiones bastante distantes del centro-occidente ${ }^{16}$.

En mi opinión, se tendría que relacionar más la discusión de los orígenes de los juegos de palo con el contexto socio-económico y cultural. Es sabido que la región del Tocuyo, indicada por todos como el epicentro del Juego de Garrote y del Tamunangue, fue una zona de plantación de caña, que contaba, durante la época colonial, con una substancial mano de obra esclava. Los peones que substituyeron a los esclavos negros en las haciendas y trapiches de los valles del Río Tocuyo eran también de ascendencia negra o mestiza. Es en ese medio en el que se desarollaron los juegos de palo y el Tamunangue. No debemos olvidar que la cofradía de San Antonio del Tocuyo era un hermandad para «morenos y esclavos» ${ }^{17}$. Posteriormente a la Independencia la región conservó esa presencia negra tanto en el aspecto demográfico como en el cultural ${ }^{18}$.

Lo que es menos conocido es que la práctica de juegos de palos era común en muchas zonas donde los negreros compraban su mercancia, o sea en Africa Occidental ${ }^{19}$ y en el Sur de Africa, donde existen hasta hoy día. En esta última región, muchos pueblos de ganaderos practicaban juegos de palos que les eran útiles en el trabajo con el ganado y en la defensa de los pastos. Praticaban juegos de palo los Xhosa, los M'Pondi, los Zulu y etnias de Moçambique y Angola. Entre los Zulu y los Xhosa, su uso era restringido a la adolescencia. Había juegos, torneos y peleas, o sea, existían diferentes modalidades de juego como en Lara ${ }^{20}$. Sin embargo, las evidencias

16 Canelón, [2], p. 25.

17 Ermilia TrOCONIS DE VeracocheA, Historia de el Tocuyo Colonial, 1545-1810, 2. Vols., Caracas, UCV, 1984, p. 192; Angelina PollaK-ElTZ, La religiosidad popular en Venezuela. Un estudo fenomenológico de la religiosidad en Venezuela, Caracas, San Pablo, 1994, p. 64.

18 Pedro Pablo LinÁrez, Etnohistoria del Estado Lara, Barquisimeto, Universidad Centro-Occidental «Lisandro Alvarado», 1995.

19 Para «juegos de combate» en Nigeria, algunos de los cuales usan palos, véase Edward L. PowE, Combat Games of Northern Nigeria, Madison (Wisconsin), Dan Aiki Publications, 1994.

20 Para mas información a respecto, vease William BEINART, «The Origins of the Indlavini. Male Associations and Migrant Labour in the Transkei», A.D. SPIEGEL y P. A. MCALlister (eds.), Tradition and Transition in Southern Africa, Johannesburg, 1991, pp. 103-128; Paul LA HAUSSE, «'Mayihlome!': Towards an Understanding of Amalaita Gangs

R. I., $1999, \mathrm{n}^{\circ} 215$ 
que he podido encontrar al respecto hasta ahora se concentran en Sudáfrica, porque la historia y la etnografía sobre este país está mucho más desarrollada que sobre Angola y Mozambique. Los juegos de palo llamaban la atención de las autoridades coloniales cuando los jóvenes emigrantes venían a las ciudades o las minas en búsqueda de trabajo, y constituían grupos marginales que usaban garrotes en sus enfrentamientos entre ellos o con la policía. Haría falta comprobar más detalladamente la existencia de esos juegos entre las etnias de Angola y del Congo que sufrieron de la trata negrera hacia Venezuela.

Sin embargo, es un hecho que existían o existen juegos de palos en todas las colonias americanas donde la esclavitud africana fue de gran importancia, o sea el Caribe y Brasil, lo que refuerza la hipótesis de que el Juego de Garrote tiene también una ancestralidad africana. Una de las descripciones más antiguas que hemos podido localizar es de Moreau de Saint-Méry (1797), describiendo un juego de palo en Saint-Domingue (hoy Haiti) antes de la Revolución. Los negros esclavos, según ese autor, usaban garrotes encabullados con cueros y clavos dorados, que cubrían un tercio del palo. Reconoce su «gran destreza» y rapidez en la lucha, tanto en las puntas como en los quites. Relata que los negros praticaban dos modalidades. Una era de combate puro, donde los contrincantes terminaban ensangrentados. La otra, que el autor llama de joute o espece de lutte, era amistosa, y servía para «lucir su destreza»: «Tiene su reglas como la esgrima, un atleta nuevo suplanta al que fue vencido, y la palma es dada al mas hábil»» ${ }^{21}$.

El mismo juego, o uno muy similar, se praticaba en la isla de Dominica, como sabemos a partir de un grabado de A. Brunias, de la segunda mitad del siglo XVIII, representando una lucha entre «un negro francés» y «un negro inglés». La numerosa asistencia y la presencia de otros jugadores alrededor de los dos combatientes su-

\footnotetext{
in Durham c. 1900-1930», Stephen Clingman (ed.), Regions and Repertoires: Topics in South African Politics and Culture, Braamfontein, Ravan Press, 1991, pp. 30-59; T. Dunbar MoodIE, «Ethnic Violence on South African Gold Mines», Journal of Southern African Studies, 18, 3, 1992, pp. 584-613. Agradezco a Matthew Dean (Universidad de Essex) por ayudarme a localizar estas referencias bibliográficas.

21 M. L. E. MOREAU DE SAINT-MÉRY, Description topographique, physique, civile, politique et historique de la partie française de l'Isle de Saint-Domingue, Paris, Société de l'Histoire de Colonies Françaises, 1958, p. 71 [1. ed. 1797].
} 
giere que se trataba de un combate público, con sus respectivas reglas y rituales ${ }^{22}$.

En la isla de Trinidad era muy difundido el stick-fighting o Kalinda. En el siglo XIX, se hacían torneos también, en los patios o en espacios públicos, donde se enfrentaban los combatientes de diferentes grupos o pueblos. Cada bando tenía su campeón (kalinda king) e inclusive algunas mujeres eran reputadas esgrimadoras. Los sangrientos combates entre grupos rivales acabaron provocando la represión masiva de la polícia, en los años $1880^{23}$.

En Brasil hubo varias modalidades de juegos de palo practicados por esclavos o negros libertos. El viajero y pintor bávaro Rugendas describió «una especie de danza militar: dos grupos armados de palos ponense frente al otro y el talento consiste en evitar las puntas del adversário» ${ }^{24}$. El más conocido hoy en día es el Maculêlê, que surgió en las plantaciones de Santo Amaro, en la provincia de Bahia ${ }^{25}$. Pero el Maculêlê, por lo menos como es conocido desde la década de 1940, ya no es propiamente un arte marcial, sino más bien una danza que se baila generalmente con dos palos (con la excepción del capitán, que enfrenta succesivamente a los demás con un solo palo). Los casos del Maculêlê y del Kalinda muestran que en las sociedades de plantaciones era frecuente entre esclavos praticar juegos de palos amistosos asociados con música.

La tercera modalidad, el garrote dentro de la Batalla, ya ha suscitado comentarios de varios autores que estudiaron el Tamunangue. Juan Liscano asoció la devoción a las fiestas del solsticio y fue el primero en atribuirle un sentido agrario, lo que explicaría su popularidad en las poblaciones de conuqueros larenses. Como se mencionaba, algunos autores han insistido sobre los orígenes españoles $o$

22 Vease la ilustración reproducida en C. Herrmann MidDELANIS (ed.), Schwarze Freiheit im Dialog. Saint-Domingue 1791-Haiti 1991, Bielefeld, Fakultät für Linguistik und Literaturwissenschaft, Universität Bielefeld, 1991, illustr. no. 2.

23 Para una descripción más detallada, véase Bridget BRERETON, Race Relations in Colonial Trinidad, 1870-1900, Cambridge, Cambridge University Press, 1979, pp. 166-75.

24 «Il faut aussi signaler ici d'une sorte de danse militaire: deux troupes armées de perches se placent en face l'une de l'autre, et l'habilité consiste pour chacun à éviter les coups de pointe que son adversaire lui porte». Johann Moritz RUGENDAS, Voyage pittoresque dans le Brésil, Paris, 1835, p. 26. Véase también la edición en portugués: Viagem pitoresca através do Brasil, São Paulo, EDUSP, 1979, p. 280.

25 Algunos datos sobre la historia del Maculêlê se encuentran en Maria MutTi, Maculêlê, Salvador (Bahia), Prefeitura da Cidade, 1978.

R. I., $1999, \mathrm{n}^{\circ} 215$ 
europeos de la manifestación. Así Silva Uzcategui después de haber estudiado «muchas danzas folclóricas de España y otras de Santo Domingo» llegó a la conclusión que el Tamunangue es «una reminiscencia, una derivación de danzas folklóricas de algunas regiones de España, inclusive Canarias ${ }^{26}$. No obstante, este autor no presenta argumentos muy concretos para el caso de la Batalla, y en otra parte de su estudio reconoce la influencia africana en algunos de los siete bailes (sones) que componen el Tamunangue. Isabel Aretz, en su clásico estudio, muestra el carácter sincrético del Tamunangue. Resalta la influencia afro-venezolana sobre todo en el Chichivamos, la Juruminga, el Poco a Poco, y la Perrendenga, que se manifiesta en la música, en el baile o en la pantomima ${ }^{27}$.

Aunque no se puede aislar la apreciación de la Batalla de una discusión más general sobre el carácter del Tamunangue, intentaré por ahora concentrarme sobre el uso del garrote en esa manifestación. En el Tamunangue no se usan garrotes ordinarios, sino «varas» decoradas de manera específica. Esa vara es uno de los símbolos del santo, y por lo tanto se usan no solamente en la Batalla, sino también en los otros bailes, como en la Perrendenga, «donde la mujer y el hombre simulan pasos de la Batalla, pero como bailando. Sin una lucha $\tan$ cerrada ${ }^{28}$.

La función del garrote y de la Batalla es tan central al Tamunangue que en un estudio reciente lo han relacionado con el teatro evangelizador y de conquista ${ }^{29}$. En efecto, la Batalla, en la visión de los tamunangueros, es siempre explicada por la victoria de los españoles sobre los moros, y por extensión, sobre los indios americanos. De esa manera, parece muy probable que exista algun vínculo entre la danza de Moros y Cristianos en España y el Tamunangue venezolano. Aún más, Julio César Baroja en sus trabajos sobre fiestas populares del verano en España ha destacado «la conexión que, desde anti-

26 R. D. Silva UzCATEgui, Enciclopedia Larense, 2 vols, Caracas, 1969, pp. 164, 169; y R. D. Silva UzCategUI, «Raíces hispánicas del Tamunangue», Elite (Caracas), 1954.

27 ARETZ, [5], pp. 103, 110, 119, 128.

28 Miguel CARDONA en ARETZ, [5], p. 126.

29 Norma GONZÁLEZ VILORIA, El Tamunangue como teatro de imitación y simbólico de la realidad. Tésis de Maestria en Literatura Hispanoamericana, Caracas, Universidad Pedagógica Experimental Libertador, 1991, p. 36. 
guo, se establece entre las danzas militares, con la de espadas en cabeza y las de «moros y cristianos» ${ }^{30}$.

Sin embargo, esa relación es mas fácil detectarla al nivel del significado general de esa manifestación, o de la posibilidad estructural de contener una lucha simbólica. Al nivel de las formas concretas que asume la Batalla, es más difícil detectar similitudes. Como ya lo ha constatado Aretz, las danzas de espadas y de palos que se practican hoy en España «no guardan similitud con las nuestras, ni en cuanto a la forma ni a las figuras. Se trata de danzas en las que actuán numerosos danzantes sincronizados, los cuales realizan una serie de figuras fijas» ${ }^{31}$. En Venezuela, existe una diversión popular en los estados de Apure y Bolívar, llamado de Paloteo, que se asemeja a los paloteados españoles ${ }^{32}$. Además, en España las danzas de palos «son considerados siempre como algo un poco burlesco, caprichoso, infantil y mudable» ${ }^{33}$ - lo que no se asemeja en nada al carácter que tiene la Batalla. Como las danzas de palos, o paloteados, tienen un carácter mas «villanesco» que las danzas de espada, hay mucho menos referencias a ellas en los textos clásicos y por lo tanto mucho menos información sobre ellos. Creemos que fue más bien por esas razones que Aretz intentó aproximar el juego de la Batalla a la esgrima de espada, y no a los paloteados propiamente dichos ${ }^{34}$. Basándose en un tratado sobre danza de un autor francés (Arbeau, 1588), se refiere ampliamente a una danza de la espada ejecutado al son de la gaita, con movimientos de esgrima. Según ella, «existe un gran similitud entre estos movimientos y los de nuestros batalleros, sea que usen palos o cuchillos». Pero de esa manera no queda claro por qué el juego de la Batalla difiere tanto, ya sea en las formas de los movimientos, o en su configuración (pareja se enfrenta en un juego improvisado) de sus supuestos antecesores españoles (mayor número de participantes, movimientos fijos, ausencia de juego).

A mi entender, se debería considerar más seriamente la eventual contribución de artes de combates traídos por los esclavos africanos

\footnotetext{
30 Julio Caro BAROJA, El estio festivo. Fiestas populares del verano, Madrid, Taurus, 1984, p. 116

31 ARETZ, [5], p. 87.

32 Luis Arturo Domínguez y Adolfo SALAZAR QuiJADA, Fiestas y danzas folklóricas en Venezuela, 2. ed., Caracas, Monte Avila, 1992, pp. 165-169.

33 BAROJA, [30], p. 113.

34 ARETZ, [5], pp. 84-86.
}

R. I., $1999, \mathrm{n}^{\circ} 215$ 
al Juego de Batalla y al Juego de Garrote, como ya lo han sugerido Pollak-Eltz y Linárez. ${ }^{35}$ Resumo los argumentos a favor de tal interpretación:

- la existencia de numerosos artes marciales tanto en Africa como en otras colonias esclavistas de América (Brasil y Caribe) que se pratican asociados con música y baile;

- la existencia de luchas ejecutadas con palos en esas mismas colonias, siempre practicadas por los esclavos y sus descendientes;

- la existencia de las mismas modalidades de juegos (de riña, recreativo/deportivo, festivo/devocional) en otras artes marciales afro-americanas y el siempre posible pasaje de uno al otro.

Parece que la situación colonial y la experiencia de la esclavitud fueron cruciales en el desarollo de la ambiguiedad y la multifuncionalidad del garrote, permitiendo su uso en diversas modalidades.

Me ha llamado, particularmente, la atención, la importancia atribuida por los maestros de garrote a la malicia, al engaño. Aunque existen las fintas en las esgrimas de tipo europeo, no se llega nunca a constituir la malicia en categoría central en esas artes. Por lo contrario, la malicia es un concepto fundamental también en el arte marcial afro-americano más difundido y estudiado hoy en día, la Capoeira. Hay cierto consenso en la literatura de interpretar la malicia como una forma de resistencia de personas de posición social muy desfavorable, como lo era el esclavo o el negro horro en la sociedad brasileña ${ }^{36}$. Practicantes y estudiosos de Capoeira Angola (el estilo más tradicionalista) defienden el punto de vista según el cual las culturas africanas tradicionales «son holísticas, sin clara distinción entre sagrado y secular, trabajo y recreación, lucha y juego» ${ }^{37}$.

Aunque no se puede concluir definitivamente a partir de los escasos datos, estas analogías permiten delimitar el campo para futuras

35 Pollak-EltZ, [17], p. 65; Pedro Pablo LináReZ, Sones de Negros. Elementos para su discusión, Caracas, FACES/UCV, 1987, p. 6.

36 Antonio CÁNDIDO, «Dialética da Malandragem», Revista do Instituto de Estudos Brasileiros, 8, São Paulo, 1970, pp. 67-89; Roberto DA MATTA, Carnavais, malandros e heróis. Para uma sociologia do dilema brasileiro, 4. ed., Rio de Janeiro, Zahar, 1983.

37 GCAP (Grupo de Capoeira Angola Pelourinho), Introducción al CD Capoeira Angola from Salvador, Brazil. Producido por Mestre Cobra Mansa y Heidi Rauch, Washington, D.C., Smithonian/Folkways Recordings, 1996, p. 13. 
investigaciones y discusiones. Muestran la importancia de estudiar los juegos de palo dentro de su contexto social e histórico.

En la segunda parte de este artículo, analizaré el papel del garrote en las riñas en el Estado Lara, como parte de un trabajo que busca recuperar nuevas fuentes para su historia. Me parece importante el énfasis sobre el papel del garrote en las riñas, porque muchos antropólogos o folcloristas han tendido a analizar el uso del garrote en $\mathrm{La}$ Batalla aislado de su contexto social más largo.

De hecho, en el siglo XIX hubo varios movimentos de colonización a partir de los antiguos centros coloniales como el Tocuyo y Barquisimeto. En las tierras altas de los Andes larenses (Cubiro, Sanare, Guarico y los Humocaros) y en Cabudare y Sarare se desarollaran los policultivos comerciales y el café ${ }^{38}$. El café también se desarolló en la région más seca de Duaca, Aguada Grande y Bobare. Como lo ha mostrado Yarrington, pequeños productores independientes fueron responsables por la expansión del café en esa última zona en un primer ciclo hacia aproximadamente $1919^{39}$. En un segundo momento, la elite regional, apoyándose en el orden gomecista, empieza a retomar control de los baldíos, forzando a muchos campesinos a retransformarse en peones o jornaleros.

De esa manera, la cultura del Tocuyo colonial funcionó durante el siglo XIX como una especie de matriz para un área bastante amplia, englobando en algunos aspectos casi todo el Estado Lara, como se ve por la difusión del Tamunangue. Los portadores de esa cultura popular colonial pasan a ser entonces no solamente los ex-esclavos y peones de los trapiches y haciendas, sino también los jornaleros, conuqueros y hasta los pequeños comerciantes y hacendados de toda la región. Las frecuentes guerras civiles en esa región contribuyeron a una flexibilidad relativa de las fronteras étnicas y la constitución de una cultura popular regional única entre negros, mestizos, pardos

38 Pedro Cunill Grau, Geografia del Poblamiento Venezolano en el siglo XIX. 3 tomos, Caracas, Ediciones de la Presidencia de la República, 1987, pp. 1361-1403. Para datos demográficos, véase también Reinaldo RoJAS, La economía de Lara en cinco siglos. Barquisimeto, Asociación Pro-Venezuela, Seccional Lara; Asamblea Legislativa del Estado Lara, 1996, pp. 51-65. Sobre las haciendas de caña, ver María Victoria LóPEZ PÉREZ, Campesinos y peones en la hacienda-trapiche del Estado Lara, 1900-1940, Revista de Ciencias Sociales de la Región Centro-Occidental, 1, Barquisimeto, 1986, pp. 45-70.

39 Doug Yarrington, Public Land Settlement, Privatization and Peasant Protest in Duaca, Venezuela, 1870-1936, Hispanic American Historical Review, 74, 1, Durham, 1994, pp. 34-61.

R. I., $1999, \mathrm{n}^{\circ} 215$ 
y blancos. Así el Tamunangue, expresión central de la cultura popular regional, cesó de ser practicado únicamente por descendientes de negros y pasó a ser parte del patrimonio cultural de todos los grupos subalternos. Sin embargo, se conservó la costumbre entre los ejecutantes del Tamunangue de denominarse «negra» o «negro», independientemente de su color «real». Eso no significa que desapareció del todo la jerarquía de color. Por el contrario, se percibe en las fuentes judiciales una sensibilidad aguda del «color» de los individuos, que se expresa en las descripciones de los fenotipos o la atribución de colores a las personas, a pesar de que los censos no registran más informaciones a este respecto después de 1870 .

DISGUSTOS, RIÑAS Y BROLLOS. EL CONTEXTO SOCIAL DE LAS PELEAS DE GARROTE EN LARA

El doce de mayo del año 1825, el joven comerciante Antonio Ocanto, natural y vecino de Los Rastrojos, salió de su casa en la compañía de uno de sus esclavos y de su primo Pedro Ocanto. Se dirigían para Cabudare con «una punta de Ganado», o sea, cuatro reses, que iban a vender en dicho pueblo ${ }^{40}$. Iban por el Camino Real y «luego encontraron con Felix Urquiola, y se bolvió también con ellos ayudandoles a conducir las reses pro que benían dándole trabajo ${ }^{41}$. Poco abajo de la Capilla encontrarónse con Juan Antonio Silva y Eugenio Castillo, vecinos de Los Rastrojos que iban en dirección contraria.

Antonio Ocanto requirió entonces a «su esclavo que benía de puntero, aparta quantos parapetos hubiere en el Camino para que no se me prendan mis Reces». A partir de ese momento las versiones de los eventos divergen ligeramente. Juan Antonio Silva relata que apenas respondió a Ocanto que

40 Todas las citas de ese episodio son extraídas de la causa criminal seguida contra Antonio Ocanto, por herida a Antonio de Silva y Eugenio Castillo, iniciado el 12.5.1825. Causas Penales, 1825-27, Registro Principal, Barquisimeto, Estado Lara. En todos las citas subsequentes se indicará apenas el año y el bulto cuando hay varios para un solo año.

41 En las citas se usa la ortografía original. Se ha modernizado apenas la acentuación, la puntuación y la separación entre las palabras para una mejor comprensión. La ortografía de los apellidos tampoco es coherente, varía a veces dentro de una misma declaración. En ese caso escogí la de uso común actualmente. 
«el no era parapeto ${ }^{42}$, y reíterandole Ocanto que era un parapeto, le contextó [...] que mas parapeto era él, y tirandose [Ocanto] de la Mula, desnudó el Zable, y a pesar de que Castillo le suplicó, se depase de eso, le acometió y le dio tres heridas [...] en cuia sazon aconsejaba Pedro Ocanto, á Antonio, diciendole, échele, échele, échele, y dejando Antonio á Castillo, se bino sobre mí, y me hirió levemente en un Brazo».

Según la versión de Pedro Ocanto, «no se apartó el Juan Antonio Silva», montado en su burro, «como lo hizo el Eugenio Castillo». Entonces su primo Antonio «previno nuevamente», repitiendo a su esclavo

«apartese todo parapeto, que encontrase en el Camino a que respondió el dicho Silva, que mas parapeto era él, y le requirió nuevamente diciendole Negro no seas mal criado, a que le contextó Silva, mas mal criado, y despótico, sería el, y apeandose Ocanto con el machete desnudo, diciéndole, que es lo que dices, a que le respondió lo que oyes, y tirandose a el Zuelo Silva, enarboló su Garrote, y se intrincan de palabras, en este estado se metió de por medio, el que declara, deje de eso Antonio y le dijó este á Silva, salte para á fuera, y botaré el Machete para que no digas que te pego con bentaja, ollendo estas palabras Eugenio Castillo, que quedaba dentro del Monte, se salio a el Camino, diciendo que es esto contra mi compañero, que lo que es con el, es conmigo, y le contextó dicho Ocanto, aun toda vía sin haverle tirado á Silva, diciendole no sea intrépido, quien lo ha llamado a Ud. a que le contextó Castillo, mas intrépito es el, con lo que se incomodó Ocanto, y sacando el Machete que ya lo tenía embainado le tiró un planazo, y siguió tirandole uno y otros, y a los tres, le tíró un palo Castillo, y quitándoselo como pudo, le tiró de filo con el Zable, y siguió dandole planasos hasta que lo hizo coger la carrera y quando estaban intrincado, le acometió por detras Silva a darle un palo, a abrazandose el que declara con Silva le quitó el palo, a esto bolteo Antonio para atrás después que ya el otro havia huido, y le encuentra ya a Silva, una piedra en la Mano, para tirarle, y le dice para que tienes esa piedra Negro, y le tira un planazo, otro, y otro hasta que concluió tres, y en este estado se sosegó Ocanto, [...]»

La divergencia entre las diferentes versiones se explica por la clara intención de cada partido de presentarse en la luz más favora-

42 Parapeto: «Cachivache, objeto inútil o de desecho. En Lara se usa esta voz como insulto: 'Ese Hombre es un parapeto'» (Francisco TAMAYO, Léxico popular venezolano, Caracas: UCV, 1991, p. 242).

R. I., 1999, n. $^{\circ} 215$ 
ble. Los Ocantos insisten en mostrar la actitud ofensiva de Silva y luego de Castillo, primero no queriendo apartarse, después amenazándolos e insultándolos, lo que justificaba «contener» a Silva con los planazos de sable y luego corregir a Castillo. Juan Antonio Silva y su compadre Eugenio Castillo subrayan la actitud arrogante y ofensiva de Antonio Ocanto, lo que justificaba, desde su punto de vista, sus respuestas en defensa de su honor. Cada partido presenta uno de sus integrantes como tentando evitar el enfrentamiento. A pesar de las divergencias en los detalles, hay un núcleo de «datos duros» que no son contestados por ninguno de los participantes, empezando por el uso del insulto parapeto, hasta el enfrentamiento del palo con el sable ${ }^{43}$.

Este episodio, uno de los más antiguos que hemos encontrado con referencia al uso del garrote como arma, ilustra perfectamente algunos de los temas que la historia social del garrote permite desvelar. Muestra cómo el garrote se inserta en una trama, regida por un universo de símbolos, que expresan, cada cual a su manera, la jerarquia social:

\begin{tabular}{|lcccccc|}
\hline A. Ocanto & [Blanco] & $\begin{array}{c}\text { Comerciante } \\
\text { de esclavo }\end{array}$ & Propietario & Ciudadano & Mula & Sable \\
J.A. Silva y & Negro & Jornalero y/o & Trabajador & $?$ & Burra & Garrote \\
E. Castillo & (Silva) & conuquero & manual & & & \\
\hline
\end{tabular}

Aunque no se le define color de piel a Ocanto, puede presumirse que se consideraba blanco, mismo siendo «blanco de orilla» ${ }^{44}$. Por esa razón él se arrogaría el derecho de tratar a Silva de «negro». Es sintomático que él tribunal lo trata como «ciudadano», denominación que no aparece cuando se refiere a Silva o a Castillo.

Este episodio puede sugerir que los hombres libres pobres del campo tenían entonces orgullo suficiente para desafiar a otro de extracción social superior. Como ocurre después del fin de la Guerra

43 Todos los participantes califican el arma de Antonio Ocanto como un sable y sólo Pedro Ocanto se refiere al arma que usaba su hermano indistintamente como «machete» y «sable».

44 En Venezuela se llamaba «blanca/o de orilla» a personas consideradas «blancas» aunque no lo sean por ascendencia. 
por la Independencia, se puede presumir que algunos principios igualitarios se vieron reforzados entre estas clases a razón del conflicto. $\mathrm{Al}$ mismo tiempo, el insulto del comerciante refiriéndose explícitamente al (supuesto) color de piel de su oponente, muestra que los que se consideraban más alto en la jerarquía social no lo aceptaban.

Sin embargo, el resto de la historia parece confirmar que la jerarquía social seguía en pie, a pesar de la guerra civil devastadora de 1810-24. Castillo pagó muy caro la defensa de su compañero: se quedó manco de los tres dedos y gravemente enfermo. Además, como expuso al tribunal, «fluctuo bajo la maior miseria cargado de muchos hijos, muger y familia, sin otros axcilios para el diario alimento de ellos, que los centisimos que me rendían mis brasos» y pidió el pago de alimentos a costa del reo. Logró convencer al juez a que ordenara el embargo de los bienes de Ocanto. Pero el padre de Antonio, Merced Ocanto, dueño del establecimiento comercial de la familia, declaró que su hijo «no tenía otros bienes, que su persona, y la ropa de su uso, que tiene en su poder».

A pesar de haber herido gravemente a Castillo, no siguió preso Antonio Ocanto por mucho tiempo. En cuanto Castillo, se vió condenado a la indigencia, la enfermedad y la inválidez permanente, Antonio Ocanto fue condenado, el 25.6.1825, a pagar los costos del proceso y del médico (que sumaban $406 \mathrm{Bs}$.) y a un año de destierro. Así, apenas seis semanas después del hecho se encontraba gozando de plena libertad. El destierro de la región puede ser visto más bien como una protección de su persona que como una punición.

Este episodio muestra cómo hombres que se enfrentaban en un típico conflicto por la preeminencia ya usaban el garrote desde por lo menos el inicio del siglo XIX.

Otro caso de esa misma época es el expediente contra Francisco Hernández. Gordiano Abredo, un abastado vecino de Cabudare, pues tenía «sus lavores, donde trabajan peones para la siembra de primavera», contaba que, encontrándose en la casa del señor Miguel Paredes, sitio de Bureche, donde asistió en enero de 1826

«a una diversión de vayle (sic) que honrosamente tenia este señor el sábado [...]; pues haviendo llegado a esta casa como a las siete de la noche no tube él logro de mira siquiera la sala donde se hallava la concurrencia porque estando hayí en el Patio arrescotado sobre una Burra, resultó improvisamente y sin las menores palabras buenas, ni malas, pues no tengo con éste mi ofensor, ni siquera una mediocre amistad tirarme

R. I., $1999, \mathrm{n}^{\circ} 215$ 
de palos; y como quisera que me encontró merme (sic), inesperado, se aprovechó de estos momentos dandome el primero palo en la Espalda, y el segundo en la cabeza de modo que destos tube que yr al suelo, pues me rompió y luego después de estar en tierra siguió segun me dicen cuando he rresucitado de mi Letargo dándome con el garote concecutivamente como lo dicen todas las rroturas que en ella tengo, es verdad que apesar de mi espiritu ser quieto, pero como quiera que la defensa es natural, pude haverme libertado de algunos de estos tiros pero la desgracia me tomó sin armas» ${ }^{45}$.

El agredido sigue denunciando a Hernández, que

«no es un vecino [...] y si un hombre perturbador de la paz, ociosso, mal entretenido pues los señores honrados de aquel lugar no pueden precervar una divercion por que si llega este indibiduo, toma un gran desconcierto de modo que antes y después de embriagado [...] siempre lo verán armado de instrumentos ofensivos con el objetivo de maltratar los vesinos...»

Abredo requiere que se le reconozcan las heridas y que los vecinos testimonien que Hernández es

«un hombre quimérico, provocativo, alevoso, y amigo de reñir y peleas, y cí es verdad que este como que anda con este fin no se encuentra de otro modo por los caminos que armado de su arco, y carcajo de flechas y su cuchillo, también digan si es vago y nada cumplidos con sus obligaciones, pues no existe de otra industria que de la vagedad ...»

No obstante acusado de vago, Hernández es arrestado al día siguiente en su conuco de maíz y conducido amarrado a la cárcel de Cabudare. Declaró en su defensa que concurrió al baile «como uno de tantos que allí había» y que

«aconteció lo mismo que ordinariamente sucede en iguales concurrencias quando no hay autoridad presente a que respecten [...], este sujeto se descomisió conmigo, en tiempo que no estava yo en términos de sufrir y hace el arroyo, en mi defensa, e darle unos palos, y hacerle en la cabeza dos otras lebes heridas de tan poca concideraración, que en muy pocos dias estuvo sano, y bueno».

45 Gordiano Abredo contra José Francisco Hernández, por herida. Año 1826.

R. I., $1999, \mathrm{n}^{\circ} 215$ 
En la siguiente declaración llegó a alegar que Abredo le jaló por un brazo cuando estaba montado en una burra, que éste le ofendió verbalmente y que como cargaba un cuchillo o machete a la cintura procuró usarlo.

Infelizmente para el reo, los otros testigos confirmaron la versión de Abredo, le calificaron de «peleador», «que ha tenido varias quimeras con varias personas de aquel vecindario» y que «en aquel lugar todos le tienen miedo». Así, aunque era primo del dueño del «fandango», no tuvo a nadie que interviniera a su favor. Pero como no había tampoco testigo directo de su primera agresión y las heridas eran leves, no hubo, aparentemente, una condena ulterior ${ }^{46}$.

Aunque no podemos concluir sobre la veracidad de cada versión contada, el episodio ilustra varios aspectos del uso del garrote. Primero, que, ya en esa época, los varones iban a bailes armados de garrotes. Segundo, que, si había peleas por ocasión de bailes en casas particulares, éstas acostumbraban a desarrollarse fuera de la casa, y, como en este caso, en el patio. El patio constituía así un espacio intermedio entre la calle y la casa. Finalmente, que en la época de la Independencia, los «guapos», como se llamarían ulteriormente los varones con gusto por la pelea como Hernández, ya cargaban garrotes, aunque en esta época todavía usaban armas indígenas como arcos y flechas.

Estas son las referencias más antiguas que he encontrado al respecto del uso del garrote en el Archivo del Registro Principal de Barquisimeto. Ellas atestan la cotidianidad de su uso ya al inicio del siglo XIX. A lo largo de ese siglo y en la primera mitad del XX, el garrote continuó siendo un arma popular en todo tipo de enfrentamiento. La primera Diputación Provincial de Barquisimeto, prohibió, ya en 1832, el uso de garrotes «en poblado como en el campo en reunión» ${ }^{47}$. Pero establecía una clara distinción entre «armas prohibidas», que, encontradas sin licencia, resultarían en una multa de cuatro pesos o tres días de cárcel para su portador, y el garrote, el uso del cual en las circunstancias referidas apenas, resultaría en una pena de veinticuatro horas de arresto. $\mathrm{O}$ sea, el garrote no era prohibido fuera de los poblados y reuniones. Aunque la prohibición fue

\footnotetext{
46 Por lo menos no consta en el expediente ninguna sentencia.

47 DIPUTACIÓN PROVINCIAL DE BARQUISIMETO, editado por Francisco CAÑIZALES VERDE, Resoluciones, peticiones, correspondencia de la Primera Diputación Provincial de Barquisimeto, 1832, Vol. 1, Barquisimeto, Centro de Historia Larense, 1992, p. 50.
}

R. I., $1999, \mathrm{n}^{\circ} 215$ 
reiterada en años siguientes ${ }^{48}$, no parece haber surtido el efecto deseado esa sutil diferenciación, y los hombres de la provincia de Barquisimeto continuarían cargando garrotes, fuera en el campo o en los poblados, solos o en reunión.

Concentré mi investigación sobre el período 1890-1930, porque la documentación es más densa y por tratarse de un período de transición importante, durante el cual el estado gomecista intenta, y en gran medida logra, imponer el monopolio de la violencia. Fueron examinados los bultos referentes a cada tercer año de los expedientes criminales de esa época, o sea, los años 1890, 1893, 1896 etc. hasta el año 1929. El total de 1276 expedientes puede ser considerado una muestra representativa. Los crímenes más comunes son heridas (594 ó 47\%) y homicidios (325 ó 25\%), seguidos de hurtos (126 ó 10\%) y amenazas (80 ó 6\%). Garrotes fueron el arma principal en apenas $1,8 \%$ de los casos de homicidio, pero se usaron como arma principal en $14,7 \%$ en los casos de heridas. Además, aparecen como arma secundaria en 5,6\% de los casos de homicidio y en $9,8 \%$ de los casos de heridas. O sea, el garrote es implicado en un total de 7,4 \% de los casos de homicidio, y en $24,5 \%$ de los casos de heridas.

Estos números permiten una primera conclusión: el uso del garrote en una pelea casi nunca llegó al extremo del homicidio. Por el contrario, en la mayoría de los casos las heridas inferidas con garrote eran calificadas de leves por los peritos.

Cualquer intento de cuantificación de esos expedientes es necesariamente reductor porque no logra dar cuenta del complejo contexto específico y amalgama meras «averiguaciones sumarias», sin consecuencias mayores para los acusados, con expedientes que resultaron en procesos judiciales y condenas. Sin embargo, creo que se puede intentar una lectura que busca abstraer de ellos algunos mecanismos básicos sobre la manera como se estructuraban enfrentamientos violentos con garrotes y otras armas en la época considerada.

En primer lugar, el local del enfrentamiento. No es de extrañarse que un número significativo de peleas, aproximadamente un tercio, se iniciaban dentro de la pulpería, ya que la pulpería fue el principal local de interacción social en la sociedad venezolana tradicional.

48 DIPUTACIÓN PROVINCIAL DE BARQUISIMETO, editado por Francisco CANIZALES VeRDE, Ordenanzas, Resoluciones, Decretos, Acuerdos y Comunicaciones, 18331857, Vol. 2, Barquisimeto, Centro de Historia Larense, 1992, p. 25, Ordenanzas, Resoluciones, Decretos, Acuerdos y Comunicaciones, 1832-1837, Vol. 3, 1994, p. 109. 
Aunque el conflicto empezaba ahí, a veces los contendientes se desplazaban a la calle antes de empezar el enfrentamiento propiamente dicho. Como describió un testigo «salieron en un broyo para afuera [de la pulpería]» ${ }^{49}$.

Algo análogo ocurre con los conflictos que comenzaban en casas particulares (incluyendo las haciendas), local de otro tercio de actos violentos. Frecuentemente, a la demanda de uno de los participantes y cuando no se trataba de conflictos intrafamiliares, los adversarios se desplazaban al patio, como para significar respeto al hogar y al dueño de la casa, aunque está apenas a algunos metros de la casa o pulpería - mas también para poder pelear mejor. Así, contó un herido que en la fiesta de su casa, uno de los músicos, después de acabar de cantar y dar las buenas noches, «llevándose por la mano para atrás de la casa» a otro, «diciéndole, que aquí era donde se iva a entender con el...» ${ }^{50}$. O como en la noche de San Juan en una casa en La Miel, que «llegó allí también Francisco Amaro, desafiando a José Guedez, y cuando este salió al patio de la casa, fue que Francisco Amaro le dió los palos y lo rompió.... ${ }^{51}$

Así la calle o el patio acabaron siendo los sitios predilectos para peleas, sobretodo las que eran precedidas de discusiones y desafíos verbales. Pocos conflictos violentos se desarrollaban directamente en los campos, rozas o conucos. Más frecuente como lugares de enfrentamiento eran los caminos en el campo.

Aunque muchos conflictos violentos parecen no tener hora para hacer eclosión, hubo momentos más propicios que otros. Los encuentros en las pulperías no sólo se daban apenas durante el breve acto de la compra de mercancías, sino también cuando los hombres se quedaban ahí para conversar, beber o jugar.

Otra ocasión frecuente para los conflictos se daba durante las fiestas. Tanto bailes danzantes como velorios eran otras ocasiones de encuentro de vecinos y familias extensas, y como la mayoría de conflictos ocurrían entre personas conocidas, estas fiestas podrían ser la oportunidad para saldar enemistades antiguas, o por lo menos facilitaban la irrupción de éstos. Por eso, una pregunta constante en los interrogatorios era si hubo un «disgusto anterior». Las fiestas solían

\footnotetext{
49 Criminales contra Pablo Pérez y otros. [No. 157,] Bulto 120, Año 1914.

50 Criminales contra Cosme Damián Sequera por heridas. [No. 18,] Bulto 57, Año 1893.

51 Averiguación sumaria contra Manuel Colmenarez por heridas. [No 33,] Bulto 151, Año 1926.
}

R. I., $1999, \mathrm{n}^{\circ} 215$ 
ser también un sitio propicio para que surgiesen conflictos nuevos entre personas amigas hasta entonces. Muchas peleas se daban, según los testimonios, entre personas que anteriormente mantenían relaciones de amistad. Es que el propio contexto de la fiesta presentaba muchas situaciones propicias para la eclosión de un conflicto nuevo. La presencia de un gran número de mujeres y hombres en un espacio reducido multiplicaba las razones para que éstos se sintieran celosos, y la presencia de aquellas los forzaba a no «perder la cara» en público.

Pueden distinguirse varios tipos de conflictos que terminaban con muertos y heridos. El primero es cuando hay una agresión simple e inmediata. El agresor, usualmente por un disgusto anterior, atacaba a su víctima, sin aviso previo. La víctima no tenia tiempo ni medios para defenderse. En otros casos, reaccionaba y a veces lograba tornar la situación en su favor.

El segundo caso es cuando surgía una discusión entre dos personas que degeneraba en insultos verbales y luego en agresión física. Muchas veces intervenían terceras personas que intentaban y lograban detener la pelea. Estas personas por lo general son amigos de los contrincantes, el dueño de la casa o el jefe del caserío. Así, declara Fortunato Goyo, jefe del caserío «Londres» del municipio Sanare, que el Lunes 15.2.1926

«me encontraba yo en la casa de Salomé Escobar, donde había una reunión de personas con el propósito de esperar el Cura que andaba en miciones por esos lugares, el cual no llegó por enfermedad, y entonses la reunión resolvió vailar, y como a las doce de la noche hubo un broyo en el patio de dicha casa de Escobar, y encontrándome yo en la sala donde se vailaba salí como autoridad al punto donde el broyo, con el fin de impedir cualquer resultado y estando allí en el broyo, vide que José Antonio Linares le sumbó un palo a Marcos Perez y se lo pego en el brazo izquierdo y Marcos Pérez le sumbó otro que no sé si se lo pego y yo rapidamente los desaparté y cojí a José Antonio y lo retiré a distancia poca y le dije que se estuviera allí...» ${ }^{52}$

Detener una pelea era una tarea delicada, y muchas veces los mediadores se involucraban también en ella, y acababan siendo la víctima. Así el comerciante Luis Herrera de Quíbor contó que: 1926.

52 Criminales contra Exequiel González por homicidio. [No. 13,] Bulto 151, Año 
«ayer tardecita estaban jugando Evangelista Colmenarez y Gracio Aguero y yendo frente a la pulpería de Ramon Freitez y como discutieron [...], yo que estaba de lado adentro de la pulpería dicha, les dije como jugandome con ellos, que ci no peleaban, entonces Gracio me dijo a insultar y a desafiar. Yo salí creyendo que era verdad lo que él me decía y dieciendole que no peleaba. Cuando ya yo estaba de lado afuera, se me vino encima con un cuchillo en la mano y yo sacándole el cuerpo hasta que llegué a la orilla del empedrado, tropece y caí. Allí fue donde llegó Gracio y me puñaleó estando en el suelo. Entonces llegó Froilan Aguero y le quitó el cuchillo y si no me hubiera matado ${ }^{53}$.

El tercer caso es el de una riña entre dos que se generaliza. En algunos casos parece haber grupos antagónicos bien definidos que esperaban nada más algún pretexto para enfrentarse. Así durante una fiesta de velorio en el barrio de la Ermita, en Quibor, hubo «disgusto» entre varios hombres y se evitó una pelea por la intervención de unos «apartadores». Algunos de los «disgustados» se separaron entonces de la fiesta y se retiraron a una pulpería próxima. Como cuenta un participante,

«de alli salieron juntos todos los muchachos y se dirijieron hacia una pulpería que queda cerca de la casa del velorio adonde estuvieron tomando aguardiente: estando allí se abrieron hacia un lado de dicha casa, Juan Bautista Liscano Peraza y Eliodoro Peraza, armado el primero de cuchillo y garrote, y el segundo de peinilla, y entonces se metió Victor Manuel Gímenez armado de cuchillo y garrote en defensa de Eliodoro y en contra de Juan Bautista Liscano Peraza y Francisco Rivero; entonces le sumbó Eliodoro un planazo a Francisco, y este le tiró un toletazo a Eliodoro, entonces se metió Ramoncito a favor de Eliodoro y de Victor Manuel, y le tiró un palo a Francisco, cayendo este al suelo; Francisco entonces se paró y de cuchillo en mano le barajustó á Ramón, el cual corrió a favorecerse detrás de Eliodoro, Francisco le sumbaba cuchillo y Eliodoro gritaba: 'déjenme, no me tiren'... .» ${ }^{54}$

Como se ve por el ejemplo, en estas riñas colectivas era frecuente el uso de varios tipos de armas, habiendo una escalación hacia las más mortales. En apenas $15 \%$ de los casos de riña el garrote 1908.

53 Criminales contra Graciano de Jesús Aguero por riña. [No. 28,] Bulto 94, Año

54 Criminales contra Juan Bautista Liscano Peraza por riña y homicidio. [No. 101,] Bulto 64, Año 1896.

R. I., $1999, \mathrm{n}^{\circ} 215$ 
fue responsable por las heridas o el homicidio que llevaron a la ulterior iniciación del expediente criminal, contra $50 \%$ para los instrumentos cortantes, y $35 \%$ para las armas de fuego. Sin embargo, el garrote fue usado, aunque como arma secundaria, en $40 \%$ de los casos. La asociación del cuchillo con garrote era la más frecuente, de manera que se puede decir que los dos formaban las armas habituales del varón del campo. También la técnica de pelea de cuchillo se asemejaba a la del garrote, habiendo los mismos quites para «sacarse el cuerpo» de un ataque. Por eso los profesores de garrote acostumbraban a enseñar también las técnicas del cuchillo. Y no hay que sorprenderse porque en el Tamunangue haya también una forma de Batalla ejecutada con cuchillos.

Sin embargo, había una gran diferencia de significado entre el uso del garrote y el del cuchillo. El cuchillo o los otros instrumentos cortantes usados (peinilla, machete, navaja), y con mayor razón las armas de fuego, eran más claramente ofensivas, designadas para inferir heridas graves o mortales. El uso del garrote por regla general resultaba apenas en heridas leves («contusiones») que sanaban en pocos días. Así el uso del garrote era socialmente más aceptable como manera de defenderse de un ataque, de defender el honor, sin intención ofensiva. Mamerto Flores, relatando una pelea que tuvo con otro después de una discusión en una pulpería de Quibor, explicó por qué apenas usó del garrote en esta circunstancia:

\footnotetext{
«Yo cargaba un cuchillo en la cintura pero no quise hacer uso de él, porque mi propósito no era hacerme criminal sino defenderme como hombre» 55
}

Esta actitud se reflejaba también en los tribunales, que por lo general atribuían penas más leves para los culpables de riña usando sólo garrotes.

El garrote tuvo de esta manera una función central en un tipo de enfrentamiento muy común en la época considerada. Eran duelos informales, destinados ante todo a probar el honor de los contrincantes. Siempre empezaban con desafíos verbales. En el caso relatado antes, un testigo de la cena en la pulpería informó que 1896.

55 Criminales contra Pablo Maria Silva y otros, por heridas. [No. 36,] Bulto 62, Año 
«Mamerto le dió una copa de cocuy á Pablo [Maria Silva] y este no se la aceptó: por eso tuvieron una alegación y se desafiaron á pelear» ${ }^{56}$.

\section{Ya el herido Mamerto relató otra razón:}

«[...] como a las cuatro de la tarde me encontraba en la pulpería de Ramón Alburjas cuando llegaron allí José Silva, Juan Climaco Vega y Pablo Maria Silva: a poco de estar allí me dijo Pablo Maria, después de haber desafiado a pelear a otras personas, que me saliera para el Camino real para darme otro palo como el que me habia dado su taita: yo que tenía olvidado esto me dió rabia y le dije que sí salía porque me calculaba todavía un hombresito: al salir yo, nos cruzamos unos palos y luego le quité el garrote y le dí una caida: Pablo Maria se levantó y cojió la carrera, en la carrera lo toletié [golpear con el palo] y como a la cuadra se paró, yo lo seguía, y José Silva y Juan Climaco Vega que venían detrás, llegaron allí y entre los tres me cargaron a palos; y después de un rato de brega, yo contra los tres, me vencieron y cuando ya me vieron sumamente herido y aporreado me trajeron para la pulpería de Ramón Alburjas $[\ldots] \aleph^{57}$.

Los peritos le reconocieron ocho contusiones en las mandíbulas, pulmones, antebrazos, dedos y la espalda, y cuatro heridas en los ojos y las orejas, todas de garrote, y de carácter leve y que necesitarían un mes de asistencia médica para curarse. Obviamente las versiones de los tres acusados difieren en cuanto a la pelea, y José Silva incluso llegó a acusar a Mamerto de haber usado el cuchillo:

«[...] Mamerto le tiró primero a Pablo un leñazo. Aquí largaron los garrotes y se cojieron a los brazos, Mamerto tumbó a Pablo en la lucha y lo puso debajo, y entonces llegó Juan Climaco Vega y le dió dos palos á Mamerto por la sabadilla. Se pararon, Mamerto vino á la pulpería y pidió á Ramón una copa de cocuy, Ramón no se la quiso vender, a esto le dijo Candelario Linares que se estuviera quieto, que se dejara de esos caprichos, entonces Mamerto le brincó á Pablo Maria y lo cargó á palos, éste se defendía fue atrás y le daba palos á Mamerto hasta que este le echó un palo á Pablo por la naris y lo tumbó: Pablo se paró y cojió la carrera hacia el bajío y Mamerto se le puso detras con el cuchillo en la mano: yo los seguí con el propósito de no dejarlos pelear mas, y cuando llegué al bajío donde se le paró Palo á Mamerto, me paré en medio de los dos y le exijí á Mamerto que no peleara mas: este me apartó tiran-

56 Idem. Declaración de José Silva, comerciante.

57 Idem. Declaración de Mamerto Flores, agricultor.

R. I., $1999, \mathrm{n}^{\circ} 215$ 
dome dos puñaladas que no me pego, yo le contesté con tres palos seguidos: después de esto, Mamerto se estuvo quieto, yo le exijí a Pablo que no hubiera mas nada, pero a esto le barajustó Mamerto á Pablo y le tiró un estocada que no se la pegó y Pablo le dió un palo en la muñeca donde tenia el cuchillo y no se lo tumbó: entonces Mamerto le dijo que no le sumbara mas, pero como Mamerto tenia todavía el cuchillo en la mano, yo le exijí que lo guardara y entonces lo guardó [...]».

No obstante la violencia de la pelea, terminada ésta, los contrincantes se ayudaron a curarse las heridas en lo que parece un episodio largamente arraigado por el tradicional cocuy en un día de fiesta de San Antonio, el 13 de junio 1896:

«[...] en seguida nos venimos para la pulpería y al llegar me pidió Mamerto un copa de cocuy, yo se la dí y le brindé otra a Pablo: luego pedí medio de bálsamo para curarlo y después que le curé las heridas, sacó el cuchillo para tirarme, yo le saqué el cuerpo y le dije que porque me tiraba si lo estaba curando, entonces volvió a guardar el cuchillo, se amarró la cabeza y se vino para su casa. Yo compré media botella de cocuy y me fuí con Pablo para arriba, y al regreso, ya emparrandados, nos hisó preso la Policia» 58 .

El tribunal reconoció que Pablo María Silva, provocado por Mamerto Flores actuó en legítima defensa, y que José Silva y Juan Vega concurrieran a la riña para separarlos y absolvió a los tres ${ }^{59}$. Sin embargo, como pasaron casi siete meses entre el arresto y la sentencia y como tuvieron que pagar fianza de 500 bolívares, esta riña sin duda tuvo consecuencias graves a medio plazo para los tres acusados. No obstante este riesgo y el de sufrir heridas graves, parece que eran frecuentes en las peleas entre hombres iniciados solamente después de largos desafíos. Estos desafíos tenían varias funciones. Una era localizar otro hombre dispuesto a pelear. Como lo apuntó Pitt-Rivers, la ambigüedad en el desafío permitía poner a prueba los posibles antagonistas y también evitar el tener que asumir solo la responsabilidad por la pelea ${ }^{60}$. De manera similar, en una

\footnotetext{
58 Idem, Declaración de José Silva. El pulpero Ramón Albinjas confirmó que los Silva trajeron a Mamerto Flores a la pulpería para aplicarle curativos.

59 Sentencia del 16.1.1897, confirmada por la Corte Superior del Estado Lara el 25.2.1897.

60 Julian PITT-Rivers, The Fate of Shechem or the Politics of Sex. Essays in the Anthropology of the Meditarranean, Cambridge, Cambridge University Press, 1977, p. 77.
} 
pelea en una calle del Tocuyo en 1914, cuando uno de los contrincantes lanza su provocación: «Queréis pelear?», el otro le contesta: «No, si queréis tírame» ${ }^{61}$.

La otra razón para los desafíos era que solían poner a los varones en el estado emocional adecuado para empezar la pelea. Los desafíos verbales que he encontrado en los procesos se encuadran en las definiciones del honor plebeyo estudiado por Pitt-Rivers en Andalucía, y que se generalizó en muchas partes de América Latina. Sin embargo el «machismo» latinoamericano, en sentido estricto, se caracteriza por un mayor énfasis en la virilidad que sobrepasa el modelo clásico de la cultura ibérica ${ }^{62}$. Ha sido explicada por la violencia de la conquista y de la situación colonial o relacionado a la violencia particular de las situaciones de frontera. En el caso presente, las fuentes sugieren que la masculinidad de los hombres pobres del campo, fueran ellos jornaleros, peones o conuqueros, lo mismo que pequeños comerciantes, era muchas veces construida a través de la violencia y de la competición. Como dijo Laurens: «La lógica del desafío se apoya en la ética del honor» ${ }^{63}$. En Lara se llamaba y todavía se llama «guapo» al hombre dispuesto a pelear que quiere mostrar a través de la pelea su superioridad sobre los demás. Cuenta por ejemplo un testigo que al llegar a una pulpería del distrito Quíbor y de saludar a Pompeyo Viscaya este decía:

«quién séria el mas guapo de los que allí estaban, le contestó Felix Silva en clase de broma, que el más guapo era José Ramón Urdaneta, entonces Pompeyo Viscaya se paró y halando por su revolver le dijo a Felix Silva 'Ud. es el mas guapo' dirigiéndose a el y entonces José Ramón Urdaneta y Francisco Alvarado se acercaron a Pompeyo Viscaya exigiéndole que no tirara a Felix Silva [...]» 64

Cuando el «guapo» estaba en una fiesta, cercado de familiares y amigos, su provocación podía resultar en un brollo más largo, como

61 Criminales contra Juan Pablo Pérez por heridas. [No. 145,] Bulto 122, Año 1914.

62 John Charles ChasteEn, Trouble Between Men and Women: Machismo on Nineteenth Century Estancias, Mark D. Szuchman (ed.), The Middle Period in Latin America. Values and Attitudes in the 17th-19th Centuries, Boulder and London, Lynne Rienner, 1989, pp. 123.

63 Guy LAURENS, «La logique du défi s'appuie sur l'éthique de l'honneur, Qu'est-ce qu'un champion? La compétition sportive en Languedoc au début du siècle», Annales ESC, 5, Paris, 1990, pp. 1051.

64 Criminales contra Pompeyo Viscaya por homicidio. [No. 22,] Bulto 57, Año 1893.

R. I., 1999, n. $^{\circ} 215$ 
en el caso del baile de fin de año en un caserío del municipio Guarico en 1890:

«[...] resultó que Concepción García salió diciendo quien quería pelear: que como nadie le contestó, se salió de la sala, diciendo las mismas palabras, i como nadie le contestaba, volvió para atrás i se paró en la puerta repitiendo las mismas palabras: que entonces Estanislao se acercó a Concepción echándole el brazo derecho por la espalda i riéndose, i le dijo: yo seré el que quiero: que entonces Concepción lo cogió i lo batió contra el suelo, donde lo apretó: que entonces llegó Martín armado con un tolete de palo, diciendo: 'lo que es con mi compadre Concho es conmigo` i hacia ademán de tirarle a Estanislao; mas no lo hizo porque su cuerpo estaba cubierto por el de su hermano Concepción que estabam encima: en éste estado llegó Ramón Palma a desapartarlos $[\ldots] \gg 65$

El concepto de honor masculino implicaba defenderse de cualquier intento ajeno de humillación, ya fuera en la pulpería, una casa particular o en el camino, como occurió en un encuentro en un camino de Duaca en 1923. Relata Evangelista Rivas, agricultor, que venía con un grupo de cuatro hombres de las fiestas de Agua Salada, que

«[...] nos alcanzó frente a la posesión del General Miguel Oberto, José Antonio Gonzalez quien venia en una bestia y se la tiró encima a Vicente Castro entonces éste le dijo que por que le tiraba la bestia encima y le contestó Gonzalez 'no te gusta?' entonces le dijo Vicente, 'no me gusta', yo le dije a Gonzalez que siguiera su camino y el me dijo que él era hombrecito y entonces Vicente lo acometió dándole un chaparrazo en la frente entonces Gonzalez se fue a la carrera.» ${ }^{66}$

\section{Bien diferente es la versión del herido, que cuenta que}

«alcanzé a José Sangronis y a Vicente Castro, cuando pasé cerca de ellos me gritaron, insultándome con palabras obsenas y me dijeron que me parara para que conociera quienes eran los Duaqueños, entonces yo les dije que que le estaba yo haciendo para que me insultaran y gritaran, e

65 Causa Criminal contra Concepción García y Martin García por homicidio. [No. 36] Bulto 53, Año 1890.

66 Causa Criminal contra Vicente Castro y José Sangronis por contusiones. [No. 69,] Bulto 145, Año 1923. 


\begin{abstract}
inmediatamente se tiró del burro en que venia Vicente Castro y me dió este palo que tengo en el pulmón izquierdo; yo arrié la bestia para irme y entonces José Sangronis desde arriba mismo del burro en que venía me pegó este otro palo que tengo en la cabeza y me produjo esta herida que presento al Tribunal y luego me pegaron dos palos mas una en la mano derecha y otro cerca de la oreja derecha, seguidamente arrie la bestia y me vine para mi casa del Eneal antes que me fueran a matar a palos».
\end{abstract}

En este caso, como en muchos otros, no hay manera de reconstruir una «verdad» monolítica a partir de testimonios contradictorios. Son versiones posibles de lo que puede haber ocurrido, que debían ser suficientemente plausibles para convencer a las autoridades y al tribunal. Sin embargo, hay que notar que en las dos versiones, el desafío verbal juega un papel importante en la construcción de la trama, lo que confirma la importancia de los mismos en la generación de enfrentamientos entre hombres preocupados en afirmar su honor. El «guapo» podía considerarse ofendido si no lo saludaban, o si le miraban «como enemigo» o si le exigían la preeminencia, como en el primero caso citado, de 1825.

El garrote vino de esta manera a constituirse en símbolo de virilidad, que se llevaba para cualquier sitio y del cual el varón no se deshacía, al igual que del sombrero. Cuenta el maestro Mercedes Pérez que había varones que aseguraban su garrote en el brazo que conducía a la mujer cuando bailaban. En esas circunstancias, quitarle el garrote a uno equivalía a una ofensa y podía terminar en una pelea de consecuencias fatales, como en el caso de Juan Domingo Colmenarez, del municipio Bolívar (El Tocuyo), que salió por la puerta de la casa de comercio en El Palmar,

«con un garrote en la mano, y como José Marquez vió a Juan Domingo Colmenarez, salir del dicho establecimiento, con el garrote mencionado en la mano, se dirigió José Marquez a Juan Domingo Colmenarez, y le cojió dicho garrote, y se lo jaló, pero no se lo quitó, y en esto le dijo Juan Domingo Colmenares a Marquez, no me quite mi garrote, y sacando un cuchillo que cargaba en la cintura se lo enterró en la hollita a José Marquez [...]»67.

67 Inquisición sumaria contra Juan Domingo Colmenarez y Vicente Manzanares. [No. 21], Bulto 109, Año 1911. La cita es de la declaración del testigo Juan Bautista Pérez, jornalero.

R. I., $1999, \mathrm{n}^{\circ} 215$ 
El uso frecuente del vocabulario técnico del Juego de Garrote confirma hasta qué punto entró en la vida cotidiana de la región. Por ejemplo, un herido por una puñalada en Quíbor explicaba que «le meti el brazo derecho de tapa» a su agresor ${ }^{68}$. La agilidad adquirida por la práctica del Juego de Garrote permitía a muchos evitar heridas fatales. Así, cuando Domingo Araes habló en «son de juego» a Jesús Patiño en una «posesión de labor», por lo cual éste «se disgustó conmigo y en seguida me zumbó dos machetazos y una estocada con un machete de rozar los cuales no me pegó por haber yo sacado el cuerpo ligeramente» 69 .

De la misma manera hay evidencias claras en las fuentes sobre la existencia del «juego» amistoso, sea de cuchillo o de palo. Así Juan Pablo Rodas, de 68 años de edad (sic), del caserío Buenavista de Cuara del municipio Quíbor, contó que

«Leoncio Nuñez me barjutó con un cuchillo i me cargó a puñalada las cuales me quitaba yo pié a trás, por conocer algo de juego de arma blanca; pero al fin como ya estaba aturdido i en cansancio me dominaba, en el quite de una cuchillada tropecé y caí por tierra; aquí aprovechó Nunez y me sumbó dos cuchillada en el suelo [...]» ${ }^{70}$

Hasta ahora me he referido a diferentes situaciones de enfrentamientos entre hombres, y subrayado la importancia de los desafíos anteriores. No quiero sugerir que el deseo de provocar y de probar su «guapismo» eran los únicos motivos para pelear. Por el contrario, los testimonios sugieren una gran variedad de motivos más mediatos. Los más mencionados son celos, cobros de deuda, conflictos laborales, conflictos entre miembros de la misma familia y enemistades entre familias. Todos reflejan los problemas de la sociedad más amplia. Esos motivos calificados de «disgusto anterior» en el discurso jurídico contribuyeron a la eclosión de muchos conflictos. Sin embargo, es muy difícil determinar hasta qué grado se mezclaban motivos mediatos e inmediatos. Muchos reos negaban rotundamente que tuvieron disgustos anteriores, para no admitir que hubo premeditación, lo

68 Averiguación sumaria contra Toribio Rodríguez por herida. [No. 41], Bulto 109, Año 1911. 1923.

69 Averiguación sumaria contra Jesús Patiño, Cabudare, [No. 11], Bulto 145, Año

70 Causa sumaria seguida a Leoncio Nuñez por herida. [No. 19], Bulto 79, Año 1905. 
que agravaba la pena. Otros se refugiaban en el hecho de que habían tomado alcohol y que no estaban conscientes de lo que hacían. El alcohol fue asociado a muchos crímenes violentos, mas es igualmente difícil determinar hasta qué grado fue usado como excusa tanto por los reos como por los jueces dispuestos a imponer una sentencia más blanda $^{71}$. Así la explicacion del motivo es sin duda la parte que contiene más «ficción» y menos datos objetivos en los procesos ${ }^{72}$.

¿Hasta qué punto los casos de los procesos son representativos del uso del garrote? La confrontación de las fuentes de archivo con las informaciones de la memoria oral permite mantener la hipótesis de que sólo en los casos donde hubo un descontrol del que resultaron heridos de diversa consideración, que no aceptaron los desafios, entraron en el registro policial. Es probable que se registraran sobre todo los casos envolviendo garroteros que eran menos diestros y descontrolados, al punto de golpear a un hombre en el suelo o de usar armas prohibidas. Como cuentan los viejos maestros, los más hábiles lograban desarmar al adversario y controlarlo sin provocar una lesión de mayor consecuencia, y por lo tanto no hubo expediente jurídico.

En este estadio es interesante introducir un aspecto diacrónico en el analísis. Los procesos estudiados sugieren que hubo un cambio importante en la violencia a partir de aproximadamente 1920. Debido a la prohibición de armas de fuego, aumentado por el régimen gomecista, el número relativo de homicidios tiende a bajar (véase tabla). También baja el número de armas de fuego utilizadas, y aumentó la proporción de instrumentos cortantes. El garrote logró, aparentemente, mantener su popularidad en Lara por lo menos hasta la década del cincuenta.

71 Véase al respecto del caso mexicano la discusión en William B. TAYLOR, Drinking, Homicide \& Rebellion in a Colonial Mexican Village, Stanford (Cal.), Stanford University Press, 1979.

${ }_{72}$ Natalie Zemon Davis, Fiction in the Archives. Pardon Tales and their Tellers in Sixteenth-Century France, Stanford (Cal.), Stanford University Press, 1987.

R. I., $1999, \mathrm{n}^{\circ} 215$ 


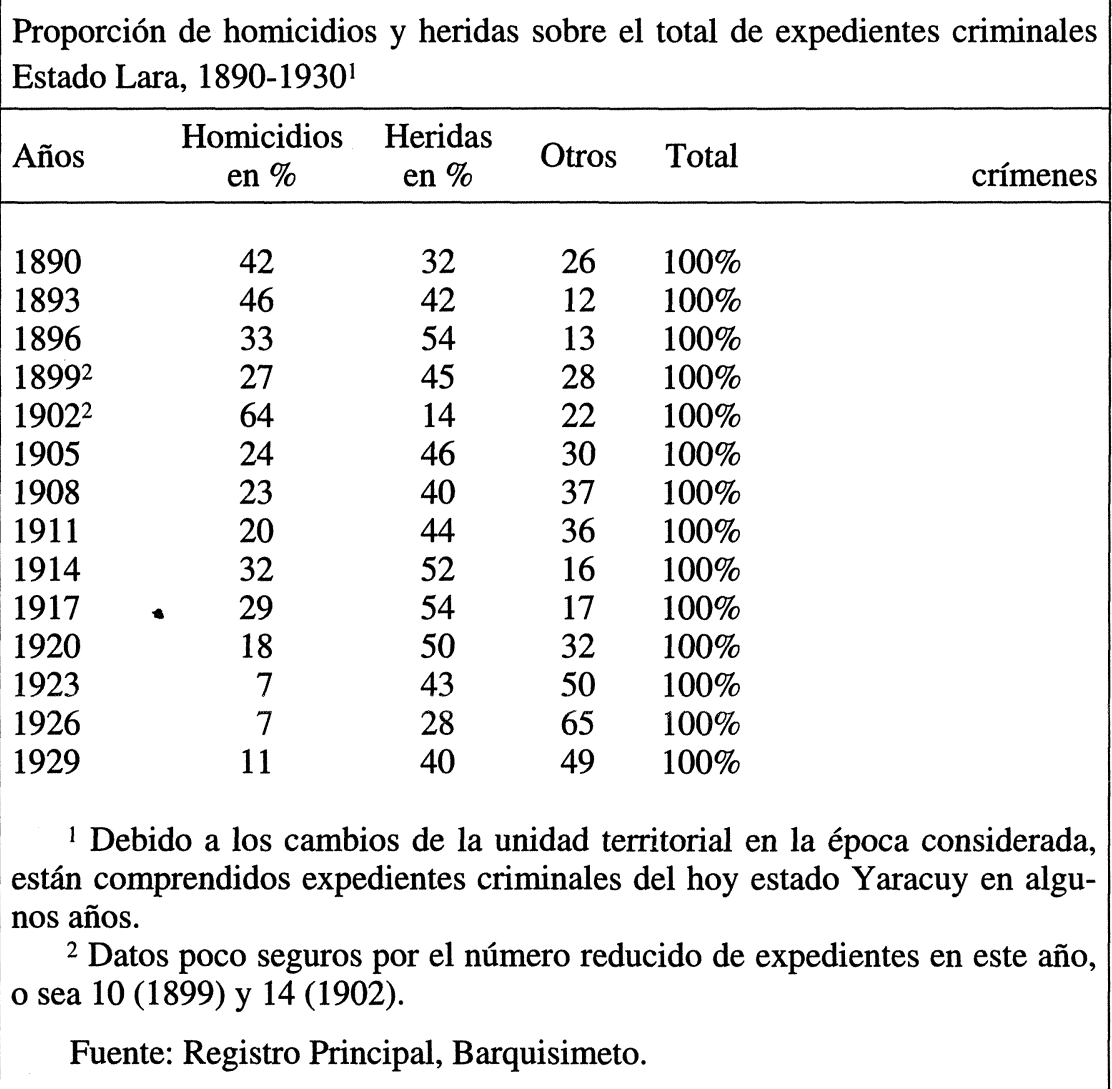

\section{CONCLUSIONES}

Tanto las fuentes de archivo como los testimonios de la memoria oral atestiguan la existencia de las tres modalidades de juegos de palo (Garrote, Batalla, Riña) desde al menos la segunda mitad del siglo XIX. Usados en una gran variedad de contextos, el garrote jugó un papel importante en la actividad social. Los juegos de palo eran parte de lo cotidiano como beber, rezar o bailar. Se cargaban en los encuentros informales, las fiestas profanas o las fiestas religiosas, en las pulperías, en los patios de las casas particulares o frente a la iglesia.

El garrote fue el instrumento predilecto de tres tipos idiosincráticos: del hombre del campo en lo general, y del «guapo» y del devoto en particular. Fue el arma del pobre del campo en su defensa contra 
la violencia cotidiana y al mismo tiempo formaba parte de la misma. Fue el arma preferida del «guapo» en los duelos donde se enfrentaban hombres subalternos como uno de los medios para probar su honor y afirmar su virilidad. Finalmente, fue el instrumento del batallero en su devoción a San Antonio en la fiesta del Tamunangue.

Si bien los orígenes del «guapismo» larense o quizás venezolano pudieran ser encontrados en una sociabilidad ibérica o mediterránea, ciertamente contribuyeron a su carácter distinto o su «colorido local», la violencia colonial y la violencia del siglo XIX venezolano. De la misma manera, si las técnicas y los movimientos usados con el garrote resultaron de una fusión de técnicas y prácticas de juegos de palo africanos, guanches y europeos, necesitaron del ambiente específico de Venezuela para transformarse y desarrollarse de la manera como lo han hecho, hasta constituirse en las modalidades que he descrito. Aunque la historia de este proceso todavía no está escrita, me parece muy justa la intuición de Sanoja de que el juego de palos «es una reminiscencia ancestral de las violencias que han forjado las patrias...» ${ }^{73}$ Similarmente, la devoción a San Antonio transciende el catolicismo romano y se puede mostrar que ahí se expresa también una forma muy africana de religosidad y toda una historia colonial hecha de esclavitud y servidumbre, de resistencia y colaboración.

Si existían claras demarcaciones entre las diferentes modalidades, estas fronteras no siempre eran rígidas. Por ejemplo, no obstante el aspecto religioso dominante, el Juego de Batalla tenía y tiene también un aspecto marcial, que según las circunstancias, es más o menos acentuado. La memoria oral de los batalleros registra muchas historias donde no se cumplió esa obligación, y donde la Batalla sirvió de pretexto para verdaderas confrontaciones entre jugadores. De la misma manera, algunos juegos amistosos acabaron en riñas verdaderas. Por lo tanto, eventualmente se pasaba de una modalidad a otra. De hecho, había una interdependencia estrecha entre las tres modalidades, cuya práctica se reforzaba mutuamente. La utilidad del Juego de Garrote se revelaba en las riñas. La destreza técnica encontraba una expresión artística y espiritual en la Batalla. La ambigüedad entre juego y pelea, sagrado y profano aseguraba una visión y una práctica holística a los aficionados de los juegos de palo.

73 SANOJA y ZeRPa, [2], p. 156.

R. I., $1999, \dot{\mathrm{n}}^{\circ} 215$ 
Sin embargo, debido a los cambios sociales y culturales desde la década de 1950 , esta estrecha relación ya no existe. La práctica de riña con garrote está practicamente extinguida, debido a que el conocimiento de las técnicas ya no es tan generalizado entre los jóvenes varones y porque han cambiado los valores y las armas. El Tamunangue pasó por un proceso de folclorización, lo que significa que el Juego de Batalla ya no es siempre ejecutado por jugadores con un conocimiento de las técnicas. El Juego de Garrote está pasando por un proceso de deportización, que puede ser uno de los medios de salvarlo de la extinción. Actualmente, hay un movimiento que busca rescatar los juegos de palos de Lara, por entender que forman parte del patrimonio histórico y cultural de la región. En mi opinión, es importante rescatarse también la estrecha relación entre las dos modalidades que todavía existen, o sea entre el Juego de Garrote y el Juego de Batalla. Perder ese vínculo, o sea, ejecutar una Batalla sin técnica adecuada o practicar un Juego de Garrote sin ninguna referencia al contexto cultural que lo originó empobrecería sustancialmente los dos. Así se conservaría verdadera y significativa la famosa copla del Tamunangue que dice:

«Los señores batalleros / No se vayan a pegar / Los rosarios están muy lejos / No hay quien los vaya a buscar.»

This article situates Venezuelan stick fighting among the wider field of European and Afro-American martial arts. The author analyses the different forms used since the early 19 th century by men in the rural areas of the state of Lara, where it is still practised today. Whereas the Juego de Garrote serves recreational and sportive purposes, the Juego de Batalla is part of a broader devotion to Saint Anthony. The criminal records show how the use of the fighting stick in the period 1880-1930 allowed the construction of a male identity (the "guapo») through the frequent fights between men. 